\title{
Overfishing, social problems, and ecosocial sustainability in Senegalese fishing communities
}

\author{
Jessica H. Jönsson
}

To cite this article: Jessica H. Jönsson (2019): Overfishing, social problems, and ecosocial sustainability in Senegalese fishing communities, Journal of Community Practice, DOI:

$10.1080 / 10705422.2019 .1660290$

To link to this article: https://doi.org/10.1080/10705422.2019.1660290

\section{(2) 2019 The Author(s). Published with license by Taylor \& Francis Group, LLC.}

\section{Published online: 04 Sep 2019.}

Submit your article to this journal $匚$

山 Article views: 30

Q View related articles $\asymp$

View Crossmark data ¿ 


\title{
Overfishing, social problems, and ecosocial sustainability in Senegalese fishing communities
}

\author{
Jessica $H$. Jönsson \\ School of Law, Psychology and Social Work, Örebro University, Örebro, Sweden
}

\begin{abstract}
This study explores living conditions of people in Senegalese fishing communities in relation to environmental change and unregulated fishing by foreign boats, weakening local opportunities and increasing forced migration of youth, creating problems for the future development of local fishery communities. It employs a postcolonial perspective and analyzes data collected through interviews with individuals from Senegalese fishing communities, social workers and relevant documents. The results show local reactions based on alliances between social workers and local community members to overfishing and the need for national and global structural changes. It is argued that EU's fishing agreements with Senegalese government is one of the reasons behind youths' forced migration to EU countries and that the betterment of the living conditions of fishery communities in Senegal requires not only already emerging alliances between social workers and local community members, but also national and global structural changes to protect Africa's fishing communities and local fisheries.
\end{abstract}

\section{KEYWORDS}

Ecosocial work; fishing communities; Senegal; sustainable development; West Africa

\section{Introduction}

Climate change and ecosocial transformations represent some of the most challenging issues facing global social work today. Climate change has led to the destruction of traditional living conditions in local communities, increasing social exclusion and marginalization, conflicts, wars and forced migration at local and global levels (Dominelli, 2012; Gray, Coates, \& Hetherington, 2013; Kamali, 2015). Such environmental changes affected local communities in the coastal areas of West African countries, such as Senegal, Liberia, Sierra Leone and Cape Verde that are mainly dependent on natural resources, such as fishing, for their living (Food and Agriculture Organization [FAO], 2018a; Tvedten \& Hersoug, 1992). As much as 40 percent of the ocean is heavily affected by pollution, depleted fisheries, loss of coastal homes and other human activities (United Nations Development Programme [UNDP], 2018). Along African western coasts, overfishing and declining fishing stocks 
have led to local exploitations of marine resources, which have impoverished the marine ecosystem (Ndour et al., 2014) and created economic and social problems leading to increasing poverty and forced migration (Alder \& Sumaila, 2004; Jönsson \& Kamali, 2012). Besides, such countries' fishing sector is drawn into a competitive industrial system through neoliberal structural adjustments, which harms and threatens the traditional fishing of local fishers and excludes them of being a competitor on equal terms in such an uncontrolled market. This has led to increasing poverty, unemployment, social stress, and declining health and well-being for local communities. Many people are forced to leave such communities in hope of being able to find jobs and take care of their families in other areas and countries, including those successfully reaching Europe (Alder \& Sumaila, 2004; Jönsson \& Kamali, 2012; Mbaye, 2014; Sall \& Morand, 2008).

This study explores the consequences of current transformations of the position of local people in Senegalese fishing communities in relation to overfishing, environmental change, the weakening of local communities and forced migration. It employs a critical postcolonial perspective and analyzes data collected through interviews with individuals from local Senegalese fishing communities, social workers and other civil actors. Further, it explores the roles and contributions of community practice for achieving environmental and social community sustainability. The following research questions have guided the study: What are local peoples' experiences from overfishing and declining fishing stocks, depletion of local marine resources and ecosystems in Senegalese fishing communities? How does the local community respond to overfishing and environmental crisis in the Senegalese fishing communities? What are the future challenges for social work in meeting the current changes in local Senegalese fishing communities?

\section{Methods}

Since the main objective of the study is to examine the situation of local people in fishing communities and how environmental and socioeconomic changes have impact on livelihoods and local opportunities, the study has a qualitative methodological approach. The study is based on 14 interviews conducted with individuals from local Senegalese fishing communities (five men and two women), social workers (two men and one woman) and other civil actors (three men and one woman), from coastal areas. Six interviews were conducted in 2010 and eight interviews were completed in 2015. The interviews have been supplemented by data collected from electronic documents and articles about local fishing communities in Senegal. The interviewees have been contacted initially through key informants in African NGO organizations in Europe. This provided the researcher with further contacts with other Senegalese 
informants who are living in European countries and in Senegal. Five of the interviewees are coming from fishing communities of the coastal areas in western Senegal (now living as migrants in European countries) and the other nine interviewees are living in fishing communities of western Senegal, in coastal areas which have been subjected to overfishing for decades. Finding those with enough knowledge and individual experiences concerning local fishing communities has not been easy. I had to use a snowball method which includes the risk of gathering information from a network of friends or members of the same family.

The collected material was analyzed using a qualitative content analysis (Downe-Wamboldt, 1992; Graneheim \& Lundman, 2004) to identify relevant themes and categories. Given the political and global content of the study, a critical content analysis was used in analyzing the empirical material (Johnson, Mathis, \& Short, 2016). Critical content analysis helps to explore discursive power relations in unequal contexts (Botelho \& Rudman, 2009) and helps to generate the latent content of interviews conducted with former colonized people and the way they are defining their own situation and the context to which they are referring. This required a combination of deductive and inductive approaches to the analysis of the data described by Mayring (2000). This has been done by applying a postcolonial perspective in order to generate relevant themes for answering the research questions. The following two main themes have been generated through the analysis of data: Hunger, social problems and forced migration, and Responses and resistance. Given the fact that Senegal is a former colonized country, the postcolonial perspective is considered relevant and necessary to understand the current situation and being able to analyze what people are telling about their everyday lives in a postcolonial world. This perspective has also helped to reduce the methodological biases influenced by unequal discursive power/knowledge relations in the process of research (Olsson, 2007) and the role of researcher in taking an advocacy role (Lindeman, 2007) representing a non-colonized country. Although interviewees' narratives are affected by the position of the interviewer within existing structural power relations, including ethnic differences between researcher and the interviewees, this does not mean that white scholars cannot do research across differences. However, we have to be aware of and challenge white privileges and question how such privilege may shape research experiences (Andersen, 1993). Such differences in power relations and using methods of conducting research across differences, which examine the living conditions of people and the conditions and circumstances that shape their experiences, requires the researcher's reflexivity and critical awareness (Andersen, 1993; Temple \& Edwards, 2002). 


\section{Theoretical framework and research context}

\section{Ecosocial transformations and sustainability in a neoliberal world order}

Environmental and social crises do not exist in a vacuum, but rather within a global neoliberal socioeconomic and political environment supporting an uncontrolled global market with the main aim of maximizing its economic revenues (Ferguson, Ioakimidis, \& Lavalette, 2018; Kamali, 2015). A way of understanding environmental change and the destruction of local communities is to consider a capitalism world system, which since the vein of colonialism and its aftermaths globalized the capitalist market and system (Wallerstein, 2017). Therefore, the matter of climate change and its local and human consequences cannot be properly addressed if the very roots of its problem, namely capitalism and the neoliberal economy are not critically analyzed, counteracted, and changed (Parr, 2013). As suggested by Naomi Klein (2014, p. 21) it is a question of capitalism vs. the climate:

... our economic system and our planetary system are now at war. Or, more accurately, our economy is at war with many forms of life on earth, including human life. What the climate needs to avoid collapse is a contraction in humanity's use of resources; what our economic model demands to avoid collapse is unfettered expansion. Only one of these sets of rules can be changed, and it's not the laws of nature.

In the case of Senegal, as for many other postcolonial nations in the Global South, neoliberal global development policies have been accompanied with increasing poverty and inequality, environmental degradation and climate change, civil war and ethnic conflict, forced migration, and the weakening of local communities. The triumph of neoliberal globalization, which started in the 1980s, structural adjustment policies forced on the country by the World Bank and the International Monetary Fund [IMF] led to destructive consequences for many African countries unable to meet the increasing needs of people who have lost their traditional livelihoods and are forced to move to urban areas or neighboring countries in search of better opportunities (Sarr, 2005; Sewpaul, 2013). Public and social services in postcolonial West Africa have gone through substantial changes influenced by postcolonial state building, globalization, uneven development, structural adjustment programs, and the inapplicability of the colonial models, which have accompanied restrictions to employment, increased poverty and social problems and growing marginalization of many groups (Sarr, 2005). Besides, and may be as a result of such changes, many such countries have been harmed by ethnic conflicts and "small wars" in the region (Kamali, 2015).

Many African countries are not only suffering from the neoliberal reforms launched by their own, often corrupted, states in cooperation with Western global organizations, but also from the unequal "agreements" forced on 
them. For example, agreements between the European Union (EU) and many African countries have resulted in the destruction of traditional life for many people in local communities, in various forms of exploitation of local resources, and have created economic and social problems in those countries (Alder \& Sumaila, 2004; Gegout, 2016; Jönsson \& Kamali, 2012). Such interventions have in many cases negative consequences for local fishery communities and destroys their traditional living conditions. In cases, such efforts of "development", as defined by the World Bank and the IMF and would be achieved by the neoliberal structural adjustment, have led to the destruction of local communities, increasing poverty, separation of families, and forced migration (Adepoju, 2003; Jönsson \& Kamali, 2012).

The failure of development policies, which do not lead to changing and improving structural inequalities and generate development in local communities, have resulted in critical approaches and concepts of sustainability. Based on a process of neoliberal globalization, the concept of sustainable development is mainly based on technocratic and capitalist Western ideology of development (Adams, 1995). After more than 50 years since the influential article of Garrett Hardin (1968) "The Tragedy of the Commons" was published, foreign destructive interventions in commons, has forced local people, who made their livings of small-scale fishery, to leave their communities in hope of better life chances somewhere else. As Ostrom, Burger, Field, Norgaard, and Policansky (1999) put it, previous generations complained that change was taking place faster and faster and population growth, economic development, capital and labor mobility, and technological change push us past environmental thresholds before we know it. However, past lessons are less and less applicable to current problems. Today, sustainable development is part of the idea of "green capitalism", which encourages consumerism as the path to development (Bruno \& Karliner, 2002). This is mainly based on a neoliberal ideology and a West-centric understanding of development, which do not target structural inequalities and promote social justice (Dominelli, 2012; Ferguson et al., 2018; Kamali, 2015).

Critical analyses are needed to unveil the underlying mechanisms behind a seemingly neutral globalization project and consider the relationship between colonialism, development and (neoliberal) globalization (McMichael, 2012). Likewise, the global profession of social work needs developing a critical position toward the ideology of global neoliberalism and its local practices. This should influence practices of social work in our postcolonial world.

Some academics argue that the "green revolution", which concerns landbased issues of sustainable development, should also include a "blue revolution" which would mean considering the question of the world's seas and oceans and its related food production, such as fishing (Soluri, 2011; Somayaji \& Coelho, 2017). Although, there are shortcomings in "The 2030 
Agenda", the Sustainable Development Goals (SDGs) and related ongoing international and national processes, which depends on the UN's ambitions of "getting onboard" as many countries as possible, the Agenda and its goals are relevant to the fisheries and aquaculture sector (FAO, 2018a). The commitment to leave no one behind in fisheries and aquaculture is a call to focus action and cooperation on efforts that will help to achieve the core ambitions of the 2030 Agenda for the benefit of fish workers, their families and their communities, for food and socioeconomic security (Lynch et al., 2017). The Agenda contains 17 Sustainable Development Goals, among those, the protection of the coastal ecosystems. Goal 14: Conserve and sustainability use the oceans, seas and marine resources for sustainable development, is a recognition of ecosocial problems of coastal areas and the need for action.

\section{Ecosocial problems and social work}

International organizations of social work (International Federation of Social Workers [IFSW], International Association of Schools of Social Work [IASSW], \& International Council on Social Welfare [ICSW]) have put forward a Global Agenda which, emphasizes the need for greater international cooperation around development issues, for acknowledging the global roots of local problems and the need for global actions. As it is stated in the Global Agenda (IFSW, IASSW, \& ICSW, 2012, p. 2) "We recognize that the past and present political, economic, cultural and social orders, shaped in specific contexts, have unequal consequences for global, national and local communities and have negative impacts on people" and therefore "feel compelled to advocate for a new world order which makes a reality of respect for human rights and dignity and a different structure of human relationships". In this respect, social work globally should "commit ourselves to supporting, influencing and enabling structures and systems that positively address the root causes of oppression and inequality". The Global Agenda emphasizes working toward environmental sustainability, strengthening recognition of the importance of human relationships and is closely related to the universal mission of social work based on its codes of ethics and the global definition of social work (IFSW, 2014). This is an important step to counteract when social work becomes a support for a neoliberal global development instead of being the agent of social change and social justice (Ferguson et al., 2018). As suggested by Gray and Webb (2013, p. 8):

In endorsing a critical social work agenda, a challenge for these international social work organizations would be to declare openly their opposition to the malign tendencies of neoliberalism and the destructive nature of state capitalism. Indeed, rather than vainly offering up sanguine diets of "Global Social Work" through best-practice models, the International Federations of Social Workers should be 
launching militant agendas, such as "In Defence of Equality: Social work Against Neoliberal Capitalism".

Since the 1990s, there has been growing awareness about the role of social work with environmental issues. New approaches of "Green social work", "Environmental Social work" or "Ecological social work" have been developed in order deepen the understanding of the relationship between human communities, their physical environment and ecosystems (e.g. Dominelli, 2012; Gray et al., 2013; McKinnon \& Alston, 2016). Dominelli (2012) describe the necessity of green social work in terms of addressing social inequalities, changing socio-economic conditions and developments rooted in neoliberalism and environmental degradation that impact disadvantaged communities. She urges social workers to support people in protecting the environment, obtain environmental justice, and to mobilize people in various partnerships and alliances that promote people's and the earth's well-being.

\section{Research context: social work in Senegal}

Senegal was a French colony and the French reforms after the Second World War were aimed at developing the proper labor force in colonies and so influenced social policy in Senegal. Social work was therefore a part of colonial policies and programs for the country. The first team of social workers was addressed in 1955 as a part of the colonial social affairs cabinet (Sarr, 2005). The first two decades after gaining independence in 1960, the Senegalese government restructured the social work intervention to help the most vulnerable groups, such as the disabled, widows and orphans. However, the structural adjustment policies forced on the country by the World Bank and the IMF in 1980 s and further neoliberalization of the country not only led to the achievement of the goals of "development" of the country, but also reinforced the country's structural and social problems (Sarr, 2005). Growing socioeconomic gaps has led to increasing social problems, armed conflicts, growing number of children living on the street, AIDS and forced migration. The failure of the state in establish a coherent social policy which would help the most vulnerable in society led to the establishment of a new policy of "mutual care" which put in reality the most burden of the social care on civil society and NGOs. This was called "traditional solidarity". Such policies of indigenization of welfare practices based on cooperation and social support networks that respond to social need and promote community well-being, which have been institutionalized in Southern African communities for many centuries (Patel, Kaseke, \& Midgley, 2012) have also been practiced in the post-war and post-colonial Senegal (Sarr, 2005). However, the indigenous system is not as strong or effective as before (Apt, 2002), partly because many people have migrated to the cities (Patel et al., 2012). There are several NGOs engaging in providing 
services to people in Senegal, such as Islamic associations and NGOs. They are organized according to their main field of activity: schooling, socio-cultural activities and (reproductive) healthcare (Renders, 2002). However, participation of people in different private and NGO projects is low since the extent of social problems and social exclusions and the weaknesses of the NGOs in providing substantial help and services (Dorsner, 2004).

The shortcomings of the NGOs to provide services to a growing number of marginalized people combined with the lack of effective social policy has led to growing social problems. Social work in Senegal is harmed by adopting Western models that have led to the erosion of traditional solidarities and local support systems, and their substitution with professional interventions through formal government and non-government services (Dominelli, 2012; Gray, 2016; Sewpaul, 2006). Recent decades of overfishing of the Senegalese shores has added to the problem of the destruction of local communities and their support systems.

\section{Results}

This section of the paper is based on the analysis of the conducted interviews and relevant documents which help to generate an understanding of the main objective of the study and its research questions. In the first part, the local peoples' experiences from and consequences of overfishing and declining fishing stocks will be elaborated on.

Analyzing the documents, such as those presented by Greenpeace (2017a) shows that West African waters are attractive for foreign fishing operations because they are amongst the most fertile in the world. Foreign fishing fleets have moved into the waters of the coast of West Africa, areas already subjected to overfishing for many years. According to Greenpeace European unit (2019), the European vessels have the capacity to catch between two and three times more than the sustainable level, which provides Europe with most of the subsidies and biggest share of fishing opportunities. By destroying the fish stocks, these foreign industries are now threatening the livelihoods of local fisherman and their families in Senegal. Documents presented by the Food and Agriculture Organization of the United Nations (FAO), show that Senegal is an example of a trend across the world, in which $90 \%$ of fisheries are fully fished or facing collapse (FAO, 2018b). Decades of overfishing have exploited artisanal fishing industries, which nations like Senegal have long relied on to for food- and socioeconomic security. Worse yet, this is happening at a time when climate change is reducing the amount of food grown own land (FAO, 2016). This transformation in Senegal is a violation of the earlier mentioned UN Sustainable Development Goal 14, which refers to Life Below Water and people depending on marine and coastal biodiversity for their livelihoods (UNDP, 2018). 
The following concerns local peoples' experiences from and consequences of overfishing and declining fishing stocks, depletion of local marine resources and ecosystems in Senegalese fishing communities.

\section{Overfishing leads to hunger, social problems, and forced migration}

Interviewees from local Senegalese fishing communities have told me about difficulties of getting fish. They have to sail far from the shore to have any chance of catching fish. In addition, the huge foreign ships in many cases destroy the local fishers fishing nets. The villagers feel angry, frustrated and powerless. A young man, Goundo originally from a fishing village in Dakar says:

... people have been fishing for generations, my father was a fisherman, my grandfather began teaching me how to fish. This situation now ... has put fishermen out of work. We fear that, in the future, there will be no fishermen left here. That is why many have fled to the Sea towards Europe ....

The worsening living conditions of people in costal fishery areas has been a narrative appearing in almost all interviews, irrespective of gender of the interviewees. As Fatou, a woman from a fishing family, says:

It is not like before, everything has been harder, fishing, working, living. We have to work much harder now to get fish, to make living, it is hard, I feel sad for my children, my family, everybody who are living here, everybody has huge problems to make living.

The current situation creates local social problems, such as unemployment, poverty, lack of health and educational opportunities, frustration and social tensions between local populations losing their traditional ways of income and livelihood. As all the interviewees point out, decreasing employment opportunities in many West African countries force young people to emigrate to large cities, where work is hard to find, or to leave for neighboring countries, and Europe further afield (see also Cross, 2013). Senegalese social workers witness the deteriorating living conditions for people in these areas as one of social workers interviewed in this study, Moustapha, with experience from working in local fishing communities in Senegal says:

... families do not have any resources and income to afford their children's education and healthcare and are living under inhuman conditions, which depends on foreign exploitation of these people's and areas resources. This leads to destructive consequences for people's livelihoods and force some to become involved in other activities in their struggle for survival; activities like crime or simply leaving their traditional villages.

People in the coastal areas of Senegal, particularly the increasing majority of young people suffer from the lack of employment opportunities, which is leading to forced migration (Adepoju, 2003; Cross, 2009). Historically, 
fishing communities in many African countries are known as being relatively immobile with sustainable living conditions. This fact has however changed dramatically since the appearance of new international fishing actors in their waters. As mentioned earlier, decreasing fishing opportunity influences many aspects of local communities' sustainable lifestyles and living conditions, forcing many youth to emigrate in search of employment opportunities. Many young West Africans end up as "illegal migrants" in other countries (Cross, 2009; Jönsson \& Kamali, 2012; Sall \& Morand, 2008). However, migration to Europe is for many a very costly and dangerous process, with major risks for migrants' lives. The desperate endeavors of many people to tackle poverty and the destruction of their traditional life chances force them to move to both urban areas in major West African cities and to Europe. This creates a new market, which even creates a new function for the old fishing boats. As one of the interviewees, a young man from Senegal, Saliou, says:

The fishing boats of the local communities formerly used for fishing now is used to transport people to Europe, even if the boats are old and not secure for taking so many people onboard that is why some of them are not reaching European coasts.

The migration journey to Europe is considered as one of the ultimate rescue mission for many young people from fishing communities in West Africa. As Muhammed says:

There is not much to do here, there is no job, no income, no security, no future, for me or for my family, I have to leave. Even in our large cities there is nothing for us, but many be going to Europe would save me from problems, getting job, income and could help my family here.

Many find it the only way out of an increasing poverty in their local communities which leave them unprotected and poor. A phenomenon mentioned by several research participants is that many families "agreed" to send young members on the dangerous journey to Europe in order for the youngsters to obtain a job in Europe and send money back to their families, as Mamoudo says:

I have to make this journey since my parents, my brothers and sisters, the entire family are dependent on me being able to send them some money for their living. Travelling to Europe is a costly business, is dangerous and I have to make it, the family give me some money, they sell their belongings for me to be able to reach Europe and take care of them .... it is not a choice, it is a duty and we have no other way .... I have tried everything ... nothing more to do.

Mamoudo's narrative is not unique and others tell more or less the same reason for their decision to emigrate to Europe. The oppressive international engagement in fishing industry in West African waters has more or less destroyed may traditional lifestyles of fishing communities and do not leave many other options than forced migration. However, although some youth 
succeed to overcome the dangers of migration and leave their deprived communities, many are left behind and have to deal with the local problems and challenges to their (un)sustainable lives.

\section{Responses and resistance in Senegal's fishing communities}

Local communities are responding to overfishing and the environmental crisis in Senegal. Communities react in different ways. Local organizations, such as NGOs and religious associations together with social workers, try to combat the local consequences of recent destructive developments in fishing communities, such as increasing poverty and disintegration of communities. One example is what is called the "crisis of youth" because of many youth leaving the community. Social workers together with other civil social actors in the area try to hinder young men from emigrating. The emigration of young men influences the demographic sustainability of such fishing communities, as Emanuelle Bouilly's study in Thiaroye-sur-Mer, a suburb of Dakar which is traditionally a fishing community, have shown. Even mothers who initially encouraged their sons to board the boats to Europe, after the death of many migrants are now trying to discourage this kind of familybased mobility (Bouilly, 2008). According to social workers, migration to both urban areas and neighboring countries as well as to European countries, where many of them end up as "illegal" migrants, is not a free choice, but an action for survival which is forced on many people who otherwise would not leave their local communities, families and their homes. As Fatima, a local social worker says:

We have tried together with local villagers, religious groups and NGOs to conduct meetings in order to convince people to stay and work for the improvement of everybody's' living conditions, otherwise they are not going to have any community left if everybody who is strong and can work leaves.

Some local social workers are organizing these meetings and are have discussions with villagers. However, this seems to be, as Fatima says, a "race against the clock". Another woman, Khadi, who works in a local NGO says:

There is no support from nowhere, not government or any other organizations, beside a few people here who work hard to change such a misery. We cannot force people to stay when there is not much to do here, no fishing, no work, no nothing. Government should take some responsibility, but I know they don't, they think only about their own pockets.

Such understanding of the role of government in supporting international engagement in overfishing in those areas is witness to the role of many postcolonial governments in West African countries. Former colonial powers and their new global organizations, such as the EU, are still trying to keep their colonial advantages by forcing "fishing agreements" on such countries. 
The local communities' experiences with the Fisheries Partnership Agreement are that they are destructive for local communities. As one of the interviewees, Abdou, puts it.

Many foreign countries, including the EU, think of their own interests and not what we, people in this local community who are living of fisheries, need for their livings. They want our fish not our development, for then they are not going to get our fish as easily as they do now. There are people in Senegal who gets benefit of such agreements but not families in need and who live of fishery.

Besides, the working conditions for social workers are increasingly worsening in fishing communities. This is mainly based on the increasing influence of foreign fishery companies and international organizations' agreements with weakening states which are retreating from their responsibilities for the wellbeing of people. Therefore, many social work activities are organized by NGOs and religious groups almost without any support from the government. However, the weakening of the traditional solidarity bonds in such communities, which mainly depend on increasing poverty, create difficulties for social worker. This forces many social workers to leave and those staying behind are working under difficult conditions. According to social worker Moustapha:

Social workers are very few and many of the educated social workers, who should stay in our countries to work with huge social problems of people who need them, are moving to urban areas or to Western countries in search of better work opportunities.

This is a serious problem for many African countries in need of a strong profession of educated social workers. However, the shortage of economic resources for many African nation-states, combined with corruption and cooperation with international actors whose interests do not coincide with those of the local communities, hinder the development of the social work profession (Sarr, 2005). Many agricultural and fishery agreements between the EU and costal African contracts have destructive consequences for local communities. This stems from the lack of a sustainable perspective on the part of the EU and the severe corruption of many African countries and governments (Jönsson \& Kamali, 2012). This makes the resistance to destructive consequences of contracts between Senegal government, EU and other international agents and companies very difficult. There will be huge challenges in changing such a destructive and unsustainable development in fishing communities.

However, there are examples of fishers who have organized themselves to protect fishing areas and demonstrated against foreign investment - and overfishing and for development alternatives like sustainable fishing practices. Such demonstrations appeared since 2011 and resulted in some cases in changing laws in order to limit foreign fishing in Senegalese waters 
(Greenpeace, 2014; Valo, 2014). This has led to the emergence of alliances between actors of civil society and social workers in helping families with limited opportunity to pursue their traditional fishing activities. There have also been reactions from international non-governmental organizations (INGOs), such as Greenpeace. As one example, in 2017, the Greenpeace ship Esperanza sailed to West Africa to "document the beauties of these rich waters, and bear witness to a growing threat to food security from decades of overfishing" (Greenpeace, 2017b, p. 1). It was called "the expedition of hope":

West African waters are a treasure we need to protect. Globally, seas are being emptied and livelihood and food security are threatened by overfishing. We sail in

West Africa to unite the region for a better management of shared fish resources.

Now it is time to act.

This was welcomed by many local fishermen desperate to combat this problem.

\section{Future challenges for social work in Senegalese fishing communities}

This research provides further evidence from fishing communities that neoliberal globalization is behind the worsening of living conditions in nonWestern countries (see also Jönsson \& Kamali, 2012; Kamali, 2015). As argued in this paper, Senegalese local fishermen are suffering from an uncontrolled global market in which foreign vessels are emptying Senegalese coastal waters from fish, which was used as way of living and making fish a profitable commodity in the capitalist global market. The Commons are using up their livelihood and "sustainable development" turns to be empty declarations. Although the protests of local fishermen showed that local mobilizations and protests can create limitations for foreign vessels, the powerful agents and their local supporters are continuing the exploitation of Senegalese waters and deteriorating commons living conditions. As argued in this paper, one of the limitations for the international social work organizations is that they have not declared openly their opposition to neoliberal politics (Gray \& Webb, 2013). Social work needs documents in which the role of globalization of an uncontrolled neoliberal market and policies is more explicitly stated and in which social work is declared as a global anticapitalistic and anticolonial movement for social change and social justice. Such documents should be given support by powerful international organizations, such as the UN and EU and other organizations aiming at improving sustainable development. Given increasing neoliberal globalization and European protectionism, social work could take a more active role in global transformations which are taking place in countries of the Global South, such as West African countries. European social workers and social work unions could make alliances with local social workers, civil actors and anticapitalistic social movements both globally and 
in West African countries in order to reinforce local resistance and engagement for change in fishing communities. Since local social problems, such as those of Senegalese fishing communities have global roots, the movements and actions against such problems should also be globally organized and supported.

Social work has many opportunities to counteract the devastating consequences of neoliberal globalization by cooperating with local community organizations and agents, national and international organizations engaged in realization of a sustainable development. The declaration of human rights (UDHR) (United Nations, 1948) and principles of social justice as emphasized in the recently adopted Global Social Work Statement of Ethical Principles [GSWSEP] (IASSW, 2018) provide guidance. The UN resolution, "Transforming our World: The 2030 Agenda for Sustainable Development" (United Nations, 2015), could make a ground for further action and measures for the protection of coastal ecosystems in West Africa. Deepening cooperation of international social work associations (IFSW, IASSW, ICSW) with the UN is needed to change the destructive trends of neoliberal globalization and its consequences for local fishing communities. This partnership should involve governments as well as people living in poverty, marginalized groups, civil society and indigenous and local communities, such as Senegalese fishing communities. Social work as a global movement could address the need for taking care of our seas and oceans as part of a "blue revolution" for combining the need of increasing global human food production and sustainability in fisheries (Soluri, 2011; Somayaji \& Coelho, 2017).

\section{Conclusion}

Destruction of fishing communities' traditional sustainable living conditions and lifestyles is far from being a local problem. The EU and other powerful countries play a decisive role in such a destructive change of local communities in West Africa which force many youths of leaving their communities and migrate to EU countries. This is problematic for the EU politicians who complain about increasing migration and suggests that they are not aware of the role of EU actors and policy in creating hardship in and driving migration from West Africa. Local communities are subjected to powerful global forces, such as the EU, national postcolonial governments in cooperation with international governments and organizations and powerful multinational companies. Such a powerful alliance creating unbearable problems for many local people, cannot be counteracted only by local actors, who are fighting an unequal struggle. Social work could play a central role for a global mobilization for change in this area. Such mobilization needs cooperation and alliance with local and global actors and awareness of the shortcomings of the international organizations' declarations and actions. In the same vein, we need a critical 
perspective on the ongoing colonizing processes that reproduce inappropriate social work approaches based on Western models.

New horizons are needed for an inclusive and anticolonial social work practice responding appropriately to local concerns, such as those in West African societies, while critically aware of the impact of international development policies on local communities (Jönsson, 2016). Local social work could be supported by national structural reforms to eliminate overfishing in coastal areas. Cooperation between the international social work associations (IFSW, IASSW, ICSW) with the UN, in realization of the declaration of human rights and an equality-based sustainable development should include people in fishing communities. Although local communities are drained of their young population, who in many cases seek their future in European countries, there are many locals who are working to make fishing communities a better place for the young generation. This, however, needs international solidarity and national governments to pay attention to a local and human catastrophe not only targeting many of such communities but also the future sustainability of food production. The crisis of the oceans transports serious consequences for the rest of the world in terms of biodiversity loss, livelihoods, fresh water, clean air, rain, and protection against climate change. Commitments for international action to protect Africa's fishing communities and local fisheries are urgently required.

\section{Acknowledgments}

Much appreciation is owed to the men and women from coastal areas and local fishing communities in Senegal, for their generosity in sharing their knowledge and experiences. Many thanks to the social workers and actors of nongovernmental organizations for participating in the study. Thanks also to key informants in African organizations in Europe for their assistance and willingness in finding contacts with interviewees and research participants.

\section{Disclosure statement}

No potential conflict of interest was reported by the author.

\section{References}

Adams, W. M. (1995). Green development theory? Environmentalism and sustainable development. In J. Crush (Ed.), Power of development (pp. 87-99). New York, NY: Routledge.

Adepoju, A. (2003). Migration in West Africa. Development, 46(3), 37-41. doi:10.1177/ 10116370030463006

Alder, J., \& Sumaila, U. R. (2004). Western Africa: A fish basket of Europe past and present. The Journal of Environment \& Development, 13(2), 156-178. doi:10.1177/ 1070496504266092 
Andersen, M. L. (1993). Studying across difference: Race, class, and gender in qualitative research. In J. H. Stanfield \& R. M. Dennis (Eds.), Race and ethnicity in research methods (pp. 39-52). London, England: SAGE Publications Inc.

Apt, N. A. (2002). Aging and the changing role of the family and the community: An African perspective. International Social Security Review, 55(1), 39-47. doi:10.1111/1468-246X.00113

Botelho, M. J., \& Rudman, M. K. (2009). Critical multicultural analysis of children's literature: Mirrors, windows, and doors. New York, NY: Routledge.

Bouilly, E. (2008). Les enjeux féminins de la migration masculine: Le collectif des femmes pour la lutte contre l'immigration clandestine de Thiaroye-sur-Mer [Women and the male migrants in Thiaroye-sur-Mer, Senegal]. Politique Africaine, 1(109), 16-31. doi:10.3917/ polaf.109.0016

Bruno, K., \& Karliner, J. (2002). The corporate takeover of sustainable development. Oakland, CA: Food First Books.

Cross, H. (2009). The EU migration regime and West African clandestine migrants. Journal of Contemporary European Research, 5(2), 171-187.

Cross, H. (2013). Labour and underdevelopment? Migration, dispossession and accumulation in West Africa and Europe. Review of African Political Economy, 40(136), 202-218. doi:10.1080/03056244.2013.794727

Dominelli, L. (2012). Green social work: From environmental crises to environmental justice. Cambridge, England: Polity Press.

Dorsner, C. (2004). Social exclusion and participation in community development projects: Evidence from Senegal. Social Policy and Administration, 38(4), 366-382. doi:10.1111/ j.1467-9515.2004.00396.x

Downe-Wamboldt, B. (1992). Content analysis: Method, applications, and issues. Health Care for Women International, 13(3), 313-321. doi:10.1080/07399339209516006

Ferguson, I., Ioakimidis, V., \& Lavalette, M. (2018). Global social work in a political context: Radical perspectives. Bristol, England: Policy Press.

Food and Agriculture Organization of the United Nations. (2016). The state of food and agriculture: Climate change agriculture and food security. Retrieved from http://www.fao. org/3/a-i6030e.pdf

Food and Agriculture Organization of the United Nations. (2018a). The state of world fisheries and aquaculture: Meeting the sustainable goals. Retrieved from http://www.fao.org/3/ i9540en/i9540en.pdf

Food and Agriculture Organization of the United Nations. (2018b). General situation of world fish stocks. Retrieved from http://www.fao.org/newsroom/common/ecg/1000505/en/stocks.pdf

Gegout, C. (2016). Unethical power Europe? Something fishy about EU trade and development policies. Third World Quarterly, 37(12), 2192-2210. doi:10.1080/ 01436597.2016.1176855

Graneheim, U. H., \& Lundman, B. (2004). Qualitative content analysis in nursing research: Concepts, procedures and measures to achieve trustworthiness. Nurse Education Today, 24 (2), 105-112. doi:10.1016/j.nedt.2003.10.001

Gray, M. (Ed.). (2016). The handbook of social work and social development in Africa. London, England: Routledge.

Gray, M., Coates, J., \& Hetherington, T. (Eds.). (2013). Environmental social work. London, England: Routledge.

Gray, M., \& Webb, S. (2013). The new politics of social work. Basingstoke, England: Palgrave Macmillan.

Greenpeace. (2014) Russian fishing trawler arrested as local fishermen in Senegal protest foreign industrial fleets. Retrieved from https://www.greenpeace.org/usa/news/russianfishing-trawler-arrested-as-local-fishermen-in-senegal-protest-foreign-industrial-fleets/ 
Greenpeace. (2017a). Exploitations of West Africa's coasts. Retrieved from https://www.green peace.org/archive-africa/en/campaigns/Defending-Our-Oceans-Hub/

Greenpeace. (2017b). The cost of ocean destruction: Report from Greenpeace ship tour of West African fisheries. Retrieved from https://storage.googleapis.com/planet4-africa-stateless /2018/10/154ab281-154ab281-the.cost_.of_.ocean_.destruction.pdf

Greenpeace. (2019). Countdown 2020 - will the EU deliver its promise of healthy seas and shift to low-impact fishing? Retrieved from https://www.greenpeace.org/archive-eu-unit/en/cam paigns/oceans/

Hardin, G. (1968). The tragedy of the Commons. Science, 162(3859), 1243-1248.

International Association of Schools of Social Work. (2018). Global social work statement of ethical principles. Retrieved from https://www.iassw-aiets.org/wp-content/uploads/2018/04/ Global-Social-Work-Statement-of-Ethical-Principles-IASSW-27-April-2018-1.pdf

International Federation of Social Workers. (2014). Global definition of social work. Retrieved from https://www.ifsw.org/what-is-social-work/global-definition-of-social-work/

International Federation of Social Workers, International Association of Schools of Social Work, \& International Council on Social Welfare. (2012). The global agenda for social work and social development: Commitment to action. Retrieved from http://cdn.ifsw.org/assets/ globalagenda2012.pdf

Johnson, H., Mathis, J., \& Short, K. G. (2016). Critical content analysis of children's and young adult literature: Reframing perspective. New York, NY: Routledge.

Jönsson, J. H. (2016). Poverty alleviation, development, and social work practice in West Africa: A focus on Senegal. In M. Gray (Ed.), The handbook of social work and social development in Africa (pp. 243-255). London, England: Routledge.

Jönsson, J. H., \& Kamali, M. (2012). Fishing for development: A question for social work. International Social Work, 55(4), 504-521. doi:10.1177/0020872812436625

Kamali, M. (2015). War, violence and social justice: Theories for social work. London, England: Routledge.

Klein, N. (2014). This changes everything: Capitalism vs. the climate. New York, NY: Simon \& Schuster.

Lindeman, N. (2007). Creating knowledge for advocacy: The discourse of research at a conservation organization. Technical Communication Quarterly, 16(4), 431-451. doi:10.1080/10572250701370056

Lynch, A. J., Cowx, I. G., Fluet-Chouinard, E., Glaser, S. M., Phang, T. D., Beard, S. D., \& Youn, S. (2017). Inland fisheries - invisible but integral to the UN sustainable development Agenda for ending poverty by 2030. Global Environmental Change, 47, 167-173. doi:10.1016/j.gloenvcha.2017.10.005

Mayring, P. (2000). Qualitative content analysis. Forum: Qualitative Social Research, 1(2), $1-10$.

Mbaye, L. M. (2014). "Barcelona or die": Understanding illegal migration from Senegal. Journal of Migration, 3(21), 2-19. doi:10.1186/s40176-014-0021-8

McKinnon, J., \& Alston, M. (Eds.). (2016). Ecological social work: Towards sustainability. New York, NY: Palgrave.

McMichael, P. (2012). Development and social change: A global perspective (5th ed.). London, England: SAGE Publications Inc.

Ndour, I., Le Loc'h, F., Kantoussan, J., Thiaw, M., Diadhiou, H. D., \& Ecoutin, J. M. (2014). Changes in the trophic structure, abundance and species diversity of exploited fish assemblages in the artisanal fisheries of the northern coast, Senegal, West Africa. African Journal of Marine Science, 36(3), 361-368. doi:10.2989/1814232X.2014.950696

Olsson, M. (2007). Power/knowledge: The discursive construction of an author. The Library Quarterly: Information, Community, Policy, 77(2), 219-240. doi:10.1086/517845 
Ostrom, E., Burger, J., Field, C. B., Norgaard, R. B., \& Policansky, D. (1999). Revisiting the commons: Local lessons, global challenges. Science, 284(5412), 278-282. doi:10.1126/ science.284.5412.278

Parr, A. (2013). The wrath of capital: Neoliberalism and climate change politics. New York, NY: Columbia University Press.

Patel, L., Kaseke, E., \& Midgley, J. (2012). Indigenous welfare and community-based social development: Lessons from African innovations. Journal of Community Practice, 20(1-2), 12-13. doi:10.1080/10705422.2012.644217

Renders, M. (2002). An ambiguous adventure: Muslim organisations and the discourse of 'development' in Senegal. Journal of Religion in Africa, 32(1), 61-82. doi:10.1163/ 15700660260048474

Sall, A., \& Morand, P. (2008). Pêche artisanale et emigration des jeunes Africains par voie piroguière [Small-scale fisheries and seaborne emigration of young Africans]. Politique Africaine, 109(1), 32-41. doi:10.3917/polaf.109.0032

Sarr, F. (2005). Changes in social policy and the social services in Senegal. In I. Ferguson, M. Lavalette, \& E. Whitmore (Eds.), Globalisation, global justice and social work (pp. 55-65). London, England: Routledge.

Sewpaul, V. (2006). The global local dialect: Challenges for African scholarship and social work in a post-colonial world. British Journal of Social Work, 36(3), 419-434. doi:10.1093/ bjsw/bcl003

Sewpaul, V. (2013). Neoliberalism and social work in South Africa. Critical and Radical Social Work, 1(1), 15-30. doi:10.1332/204986013X665947

Soluri, J. (2011). Something fishy: Chile's blue revolution, commodity diseases, and the problem of sustainability. Latin American Research Review, 46(2), 55-78.

Somayaji, G., \& Coelho, J. P. (2017). Fissures of a blue revolution: The Ramponkars' response to mechanised fishing in Goa. Social Change, 47(2), 200-213. doi:10.1177/ 0049085717696392

Temple, B., \& Edwards, R. (2002). Interpreters/translators and cross-language research: reflexivity and border crossings. International Journal of Qualitative Methods, 1(2), 1-12. doi:10.1177/160940690200100201

Tvedten, I, \& Hersoug, B. (1992). Fishing for development: small-scale fisheries in africa. Uppsala, Sweden: The Scandinavian Institute of African Studies.

United Nations. (1948). United Nations declaration of human rights. New York, NY: Author. Retrieved from https://www.ohchr.org/EN/UDHR/Documents/UDHR_Translations/eng. pdf

United Nations. (2015). Transforming our world: The 2030 agenda for sustainable development. New York, NY: Author. Retrieved from https://sustainabledevelopment.un.org/con tent/documents/21252030\%20Agenda\%20for\%20Sustainable\%20Development\%20web.pdf

United Nations Development Programme. (2018). Goal 14: Life below water. Retrieved from http://www.undp.org/content/undp/en/home/sustainable-development-goals/goal-14-lifebelow-water.html

Valo, M. (2014, February 18). Senegal fears its fish may be off the menu for local consumption. The Guardian. Retrieved from https://www.theguardian.com/world/2014/ feb/18/overfishing-factory-joal-senegal

Wallerstein, I. (2017). The world-system and Africa. New York, NY: Diasporic Africa Press. 